\title{
TITANITE CRYSTAL CHEMISTRY AND U-Pb ISOTOPIC DATA: A PETROGENETIC INDICATOR FOR PRECAMBRIAN GRANITOID PLUTONS OF THE EASTERN BRAZILIAN SHIELD
}

\author{
Danielle Piuzana $^{1 \#}$, Cristiane Castañeda ${ }^{1 *}$, Carlos Maurício Noce ${ }^{1}$, Antônio Carlos Pedrosa \\ Soares $^{1} \&$ Luiz Carlos Silva ${ }^{2}$
}

\begin{abstract}
This paper presents crystal chemistry and $\mathrm{U}-\mathrm{Pb}$ isotopic data for titanite (or sphene, $\mathrm{CaTiSiO}_{5}$ ) from Precambrian granitoid plutons of distinct tectonic settings within the Eastern Brazilian shield. Despite the fact that most titanite ages are related to partial lead-loss, resetting or crystallization during metamorphic events, chemistry data reflect the magmatic history of the plutons, specially the $\mathrm{Ti}^{4+} / \mathrm{Al}+\mathrm{Fe}^{3+}$ ratio. It is demonstrated that for plutons of different crystallization ages (Archean, Paleoproterozoic and Neoproterozoic) the measured $\mathrm{Ti}^{4+} / \mathrm{Al}+\mathrm{Fe}^{3+}$ ratios of titanite grains are characteristic of the source region from which the magma was extracted, and the ratios remain unchanged during subsequent metamorphic events. Higher $\mathrm{Ti}^{4+} / \mathrm{Al}+\mathrm{Fe}^{3+}$ values $(>9)$ are found in predominantly mantle-derived granitoid plutons whilst crust-derived granitoid rocks have lower ratios. Therefore, titanite crystal chemistry may be used to discriminate magma sources of granitoid rocks regardless their age and metamorphic history.
\end{abstract}

\section{INTRODUCTION}

Titanite can be an important petrogenetic indicator since it can incorporate by partial substitution a variety of chemical elements, such as REE, depending on the mineralogical and tectnometamorphic history of rocks. In addition, the phase relations between titanite and other Ti bearing phases (mostly ilmenite and rutile) are a function of bulk composition, pressure and/or temperature (Lambert \& Holland 1974, Enami et al. 1993, Frost et al. 2000, Kazonovitz \& Wolf 2002), and coexisting assemblage (Tropper et al. 2002). However, the incorporation mechanism in titanite of geochemically relevant elements is poorlly known (Tiepolo et al. 2002), and also the existing relations between these substitutions and petrogenesis.

The chemical composition of titanite can be represented by the general formula $\mathrm{CaTi}\left(\mathrm{SiO}_{4}\right)$ $(\mathrm{O}, \mathrm{OH}, \mathrm{F})$, but it may deviate from its ideal composition through the substitution of Ti and $\mathrm{O}$ by $\mathrm{Al}$ and $\mathrm{F}$ (Frank \& Spear 1985, Tropper et al. 2002). The $\mathrm{Al}+\mathrm{OH}$ substitution produces the end-member vuagnatite $\mathrm{CaAlSiO}_{4}(\mathrm{OH})$ - a typical low-temperature phase with a different structure than titanite (Enami et al. 1993). On the other hand, the $\mathrm{Al}+\mathrm{F}$ substitution is isostructural and is common at high metamorphic temperatures and pressures (Frank \& Spear 1985). The tittanite structure is generally described in term of chains of cornersharing octahedra, running parallel to the [100] axis and cross-linked by isolated tetrahedra. This configuration produces large cavities, where $\mathrm{Ca}$ ions in [7]-foldcoordinated sites lie (Deer et al. 1982).

In this paper, we discuss the crystal chemistry of titanite and how isomorphic substitutions may be related to its petrogenetic and metamorphic history.
The study is based on isotopic and crystal chemistry data of titanites from the São Francisco Craton and Araçuaí Orogen, in southeastern Brazil (figure1). The analysed grains come from tonalitic- to granitic plutons of distinct tectonic settings and magmatic ages.

\section{GEOLOGICAL SETTING AND SAMPLE DESCRIPTIONS}

The granitoid bodies are found in two tectonic settings, the southern part of the São Francisco Craton and the Neoproterozoic Araçuaí Orogen developed during the Brasiliano-Pan African Orogeny. The cratonic basement consists of an Archean nuclei displaying a classical association of TTG gneiss complexes, greenstone belts and felsic plutons (e.g. Teixeira et al. 2000), that is partially surrounded by a Paleoproterozoic plutonic arc (e.g. Noce et al. 2000).

The Araçuaí Orogen developed at the southeastern margin of the São Francisco Craton. Both Archean and Paleoproterozoic rock associations can be traced into the orogenic domain making up strongly reworked basement units. The orogen also comprises the volcano-sedimentary record of basin/orogen evolution, ophiolitic remnants and a calc-alkaline magmatic arc. Geochronological data for pre-, syn- and late-collisional granitoids indicate that the orogenic stage lasted from $625 \mathrm{Ma}$ to $560 \mathrm{Ma}$. A period of magmatic quiescence was followed by intrusion of postcollisional plutons at 535-500 Ma. (Pedrosa-Soares et al. 2001).

Titanite were extracted from eight samples of granitoid plutons, with magmatic ages ranging from Archean to Neoproterozoic. 


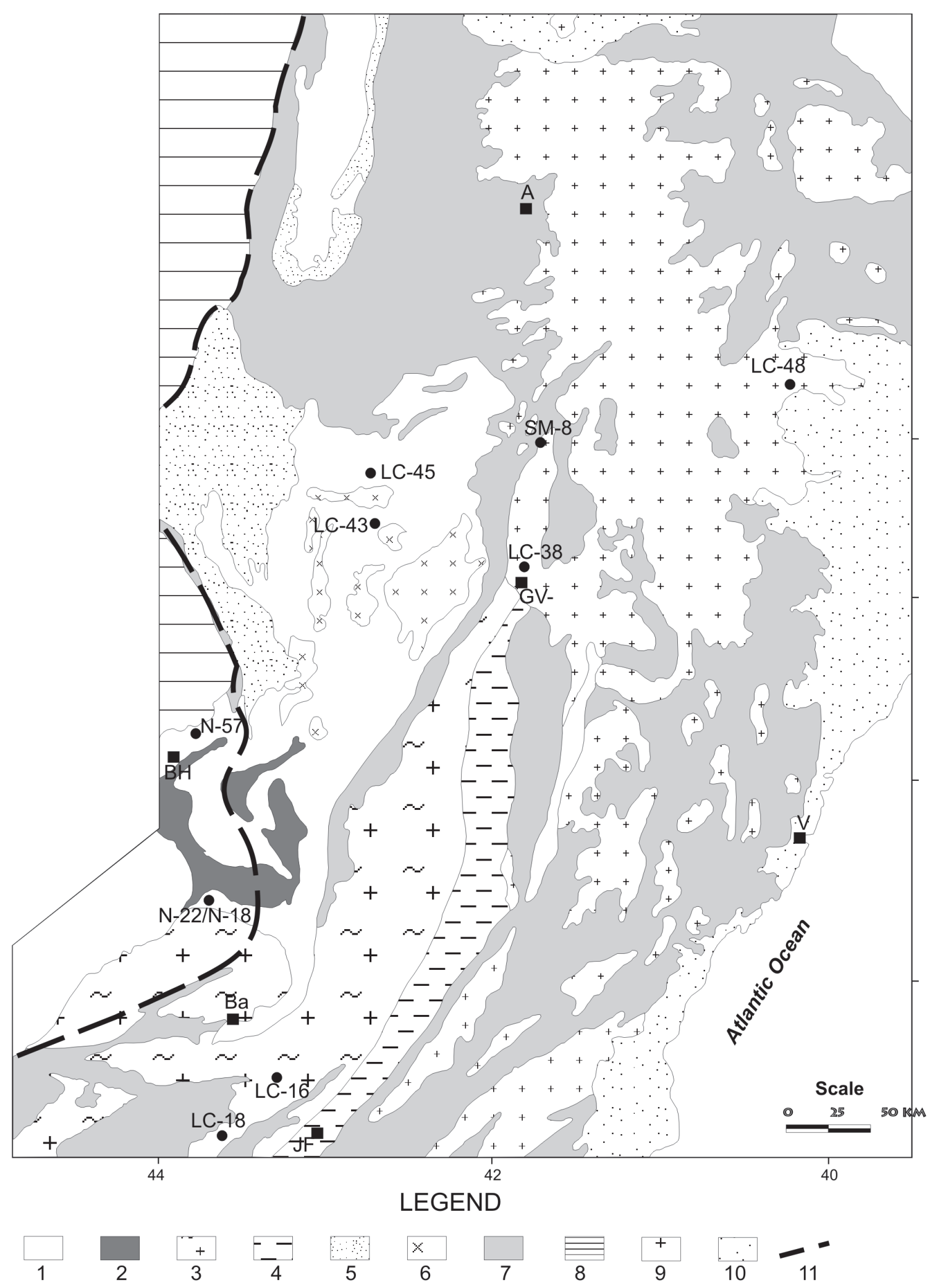

Distribution of Archean, Paleoproterozoic and Neoprotezoic studied plutons in the Brazilian Shield. Symbols: 1: Archean granitoid-gneiss-migmatitic rocks; 2 - greenstone belts and Minas Supergroup, 3 Mantiqueira Complex 4 - Juiz de Fora Complex 5 -Espinhaço rift system (Paleo to Mesoproterozoic), 6 - Borracudos Suite 7 -Supracrustals units of Brasiliano Cicle , 8 - Bambuí Group (Neoproterozoic), 9 - granites from Araçuaí Belt (Neoproterozoic marginal belt), 10 - Fanerozoic covers, 11 - Limit of São Francisco Craton. Keys: A - Araçuaí, Ba - Barbacena, BH - Belo Horizonte, JF - Juiz de Fora, GV - Governador Valadares, V - Vitória.

Figure 1: Distribution of Archean, Paleoproterozoic and Neoprotezoic studied plutons in the Brazilian Shield (modified of Pedrosa-Soares et al. 2001 and Silva et al. 2002). 


\section{ARCHEAN GRANITOIDS}

Sample N-57:

In the well-preserved Archean terrain within the cratonic domain it is possible to identify an important magmatic and tectonic event that took place at ca. 2790 to $2700 \mathrm{Ma}$, related to greenstone belt evolution and the intrusion of several tonalitic to granitic plutons (Machado \& Carneiro 1992, Machado et al. 1992, Noce et al. 2005). Sample N-57 came from a small pluton dated at 2712+5/-4 Ma (Noce et al. 1998), cutting across the much older TTG gneiss. It is a high $\mathrm{K}$ calc-alkaline and slightly peraluminous granite related to a late- to post-orogenic stage.

Samples LC-43 and LC-45:

The Guanhães Complex is a basement unit of the Araçuaí Orogen with a protracted geologic evolution that goes from Archean to Late Paleoproterozoic, strongly reworked during the Brasiliano Orogeny. Both samples are trondhjemitic-banded gneisses displaying migmatitic structures, and must represent the older TTG gneiss units within the complex. In spite of their similarity, these trondhjemite gneiss gave distinct crystallization ages of $2711 \pm 11 \mathrm{Ma}$ (sample LC-43) and $2867 \pm 10$ Ma (sample LC-45; Silva et al. 2002).

\section{Sample LC-18:}

This is a migmatitic banded gneiss with tonalitic composition, dated at $2777 \pm 22 \mathrm{Ma}$ (Silva et al. 2002). This sample belongs to another basement unit of the Araçuaí Orogen largely composed of Paleoproterozoic plutonic rocks (the Mantiqueira Complex), but including older inliers that cannot be distinguished in the field from the country rocks due to pervasive Neoproterozoic reworking.

\section{PALEOPROTEROZOIC GRANITES}

\section{Samples $N-18$ and $N-22$ :}

Several Paleoproterozoic granitoid and mafic bodies crop out along the southern border of the São Francisco Craton, making up a magmatic arc partially preserved from the Neoproterozoic tectonism. The plutonic bodies display a wide range of composition, from gabrodiorite, TTG (tonalite-trondhjemite-granodiorite), and granite (Quéméneur \& Noce 2000, Noce et al. 2000). Both samples come from the Alto Maranhão pluton, a tonalite gneissic body that is interpreted as mantlederived according to its chemical and isotopic signatures (Noce et al. 1997). Its crystallization age is given by a concordant zircon age at $2130 \pm 2 \mathrm{Ma}$, whereas a titanite discordia line yields an upper intercept at $2124 \pm 2 \mathrm{Ma}$ (Noce et al. 1998). The difference between zircon and titanite ages may be ascribed to the intrusion-cooling rate, or to a metamorphic event contemporaneous to the magmatism.
Sample LC-16:

The Mantiqueira complex consists predominantly of banded biotite-amphibole gneiss. The thickness of the the alternating layers of felsic and more mafic composition varies from centimetric to metric, and concordant amphibolite boudins, lenses and layers are very common. The felsic layers are of granitic to tonalitic composition, and this unit is interpreted as the product of intense deformation of the Paleoproterozoic magmatic arc in the Araçuaí Orogen domain. Sample LC-16 represents a tonalite layer of a banded Mantiqueira gneiss displaying milonitic texture, and yielded a magmatic age of $2052 \pm 26 \mathrm{Ma}$ (Silva et al. 2002).

\section{NEOPROTEROZOIC GRANITES}

\section{Sample SM-8:}

The Brasilândia pluton is a pre-collisional intrusion of the Araçuaí Orogen, and consists of diorite, tonalite, and granodiorite. Dating through the $\mathrm{Pb}-\mathrm{Pb}$ evaporation method yielded a minimum crystallization age of $595 \pm 3 \mathrm{Ma}$ (Noce et al. 2000). Nd and Sr isotopic data suggests a mixed magma-source involving a depleted lower crust and some mantle contribution (Martins et al. 2003). Sample SM- $8 \mathrm{c}$ is a homogeneous foliated tonalite, fine- to medium-grained.

\section{Sample LC-38:}

This sample is granodioritic gneiss with a poorly constrained intrusion age of $565 \pm 31 \mathrm{Ma}$ (Silva et al. 2002). It contains tectonic lenses of garnet-sillimanite paragneisses and may represent a syncollisional intrusion of the Araçuaí Orogen.

\section{ANALYTICAL TECHNIQUES}

Titanite U-Pb analyses were carried out for this study at the Geochronology Laboratory of the University of Brasilia, with the exception of samples N-18/N-22 and $\mathrm{N}-57$ that were analyzed previously and presented in Noce et al. 1998. Titanite concentrates were extracted from rock samples using conventional gravimetric and magnetic (Frantz isodynamic separator) techniques. Final separation was achieved by hand picking using a binocular microscope. Titanite grains were dissolved in concentrated $\mathrm{HF}$ and $\mathrm{HNO}_{3}\left(\mathrm{HF}: \mathrm{HNO}_{3}=4: 1\right)$, and a ${ }^{205} \mathrm{~Pb}-{ }^{235} \mathrm{U}$ spike was used. Chemical extraction followed standard anion exchange technique using Teflon micro columns. Isotopic analyses were carried out on a Finnigan MAT-262 multi-collector mass spectrometer, and procedure blanks for $\mathrm{Pb}$, at the time of analyses, were better than $15 \mathrm{pg}$. For data reduction and age calculation, PBDAT (Ludwig 1993) and ISOPLOT-Ex (Ludwig 2001) were used. Calculated ages are shown in table 1.

For crystal chemistry, fourteen single crystals were analyzed by electron microprobe on a JEOL JXA-8900RL spectrometer under the following 
Table 1 - Synthesis of data from studied samples

\begin{tabular}{|c|c|c|c|c|c|}
\hline \multicolumn{6}{|c|}{ Archean plutons } \\
\hline Sample & $\begin{array}{l}\text { Geotectonic } \\
\text { Domain }\end{array}$ & $\begin{array}{l}\text { Crystallization } \\
\text { Age }\end{array}$ & Titanite age & $\begin{array}{l}\text { Significance of titanite } \\
\text { age }\end{array}$ & $\begin{array}{l}\text { Nature of the } \\
\text { rock }\end{array}$ \\
\hline LC-45 & $\begin{array}{l}\text { Araçuaí } \\
\text { Orogen }\end{array}$ & $2867 \pm 10(a)$ & $506 \pm 7(* 1)$ & $\begin{array}{l}\text { Partial lead loss related } \\
\text { to the late Brasiliano } \\
\text { Orogeny (orogenic } \\
\text { collapse) }\end{array}$ & TTG gneiss \\
\hline LC-43 & $\begin{array}{l}\text { Araçuaí } \\
\text { Orogen }\end{array}$ & $2711 \pm 11(\mathrm{a})$ & $\begin{array}{l}528-434 \\
(* 2)\end{array}$ & $\begin{array}{l}\text { Resetting or } \\
\text { crystallization during } \\
\text { during the Brasiliano } \\
\text { metamorphic peak } \\
\text { followed by recent lead- } \\
\text { loss }\end{array}$ & TTG gneiss \\
\hline LC-18 & $\begin{array}{l}\text { Araçuaí } \\
\text { Orogen }\end{array}$ & $2777 \pm 22(a)$ & $\begin{array}{l}550-536 \\
(* 2)\end{array}$ & $\begin{array}{l}\text { Resetting or } \\
\text { crystallization during } \\
\text { during the Brasiliano } \\
\text { metamorphic peak } \\
\text { followed by recent lead- } \\
\text { loss }\end{array}$ & TTG gneiss \\
\hline N-57 & $\begin{array}{l}\text { São Francisco } \\
\text { Craton }\end{array}$ & $2712 \pm 5(c)$ & $\begin{array}{l}2328-2212 \\
(* 3)\end{array}$ & $\begin{array}{l}\text { Partial lead loss related } \\
\text { to the Transamazonian } \\
\text { Orogeny }\end{array}$ & High $\mathrm{K}$ granite \\
\hline \multicolumn{6}{|c|}{ Paleoproterozoic plutons } \\
\hline Sample & $\begin{array}{l}\text { Geotectonic } \\
\text { Domain }\end{array}$ & $\begin{array}{c}\text { Crystallization } \\
\text { Age }\end{array}$ & Titanite age & $\begin{array}{l}\text { Significance of titanite } \\
\text { age }\end{array}$ & $\begin{array}{c}\text { Nature of the } \\
\text { rock }\end{array}$ \\
\hline $\mathrm{N}-18 / \mathrm{N}-22$ & $\begin{array}{l}\text { São Francisco } \\
\text { Craton }\end{array}$ & $2130 \pm 2 \mathrm{Ma}(\mathrm{c})$ & $\begin{array}{l}2124 \pm 2 \\
(* 4)\end{array}$ & $\begin{array}{l}\text { Magmatic age; fractions } \\
\text { are concordant or display } \\
\text { recent lead loss }\end{array}$ & $\begin{array}{l}\text { Mantle- } \\
\text { derived } \\
\text { tonalite }\end{array}$ \\
\hline LC-16 & $\begin{array}{l}\text { Araçuaí } \\
\text { Orogen }\end{array}$ & $2058 \pm 7(a)$ & $\begin{array}{l}636 \pm 89 \\
(* 4)\end{array}$ & $\begin{array}{l}\text { Resetting or } \\
\text { crystallization during } \\
\text { during the Brasiliano } \\
\text { metamorphic peak } \\
\text { followed by recent lead- } \\
\text { loss }\end{array}$ & $\begin{array}{l}\text { Tonalite } \\
\text { gneiss }\end{array}$ \\
\hline \multicolumn{6}{|c|}{ Neoproterozoic plutons } \\
\hline Sample & $\begin{array}{l}\text { Geotectonic } \\
\text { Domain }\end{array}$ & $\begin{array}{c}\text { Crystallization } \\
\text { Age }\end{array}$ & Titanite age & $\begin{array}{l}\text { Significance of titanite } \\
\text { age }\end{array}$ & $\begin{array}{l}\text { Nature of the } \\
\text { rock }\end{array}$ \\
\hline Sm-8 & $\begin{array}{l}\text { Araçuaí } \\
\text { Orogen }\end{array}$ & $595 \pm 3(b)$ & $\begin{array}{l}564-534 \\
(* 2)\end{array}$ & $\begin{array}{l}\text { Partial lead loss and } \\
\text { resetting related to } \\
\text { Brasiliano metamorphic } \\
\text { peak followed by recent } \\
\text { lead-loss }\end{array}$ & $\begin{array}{l}\text { Pre-collisional } \\
\text { diorite- to } \\
\text { tonalite pluton }\end{array}$ \\
\hline LC-38 & $\begin{array}{l}\text { Araçuaí } \\
\text { Orogen }\end{array}$ & $565 \pm 31(a)$ & $556 \pm 7(* 5)$ & $\begin{array}{l}\text { Magmatic/metamorphic } \\
\text { age }\end{array}$ & $\begin{array}{l}\text { Sin- to late } \\
\text { collisional } \\
\text { granodiorite }\end{array}$ \\
\hline
\end{tabular}

*1-lower-intercept age

*2 - range of ${ }_{206} \mathrm{~Pb} /{ }_{238} \mathrm{U}$ ages, discordant and/or concordant analysis

*3 - range of ${ }_{207} \mathrm{~Pb} /{ }_{206} \mathrm{~Pb}$ ages, discordant analysis

$* 4$-upper intercept age *5-mean ${ }_{206} \mathrm{~Pb} /{ }_{238} \mathrm{U}$ age

operational conditions: $15 \mathrm{kV}$ acceleration potential and $20 \mathrm{nA}$ sample current. The crystals were analyzed using the following standards: jadeite $(\mathrm{Na})$, asbestes $(\mathrm{K})$, hortonolite ( $\mathrm{Si}, \mathrm{Fe}, \mathrm{Mg}, \mathrm{Mn})$, anorthite ( $\mathrm{Ca}, \mathrm{Al}$ ), chromite $(\mathrm{Cr})$, synthetic glass (REE). Counting times (a) U-Pb SHRIMP isotopic data from Silva et al. (2002); (b) ${ }_{207} \mathrm{~Pb} /{ }_{206} \mathrm{~Pb}$ in zircon crystals from Noce et al. (2000); (c) Isotopic data from Noce (1995)

were 20s for REE and 16 s for all other major elements. The chemical data for each crystal are averages of 3-7 analyses taken uniformly over each crystal. The lower limit of detection was $0.01 \mathrm{wt} \%$. Calculation of the titanite unit formula is a very difficult task due to the 

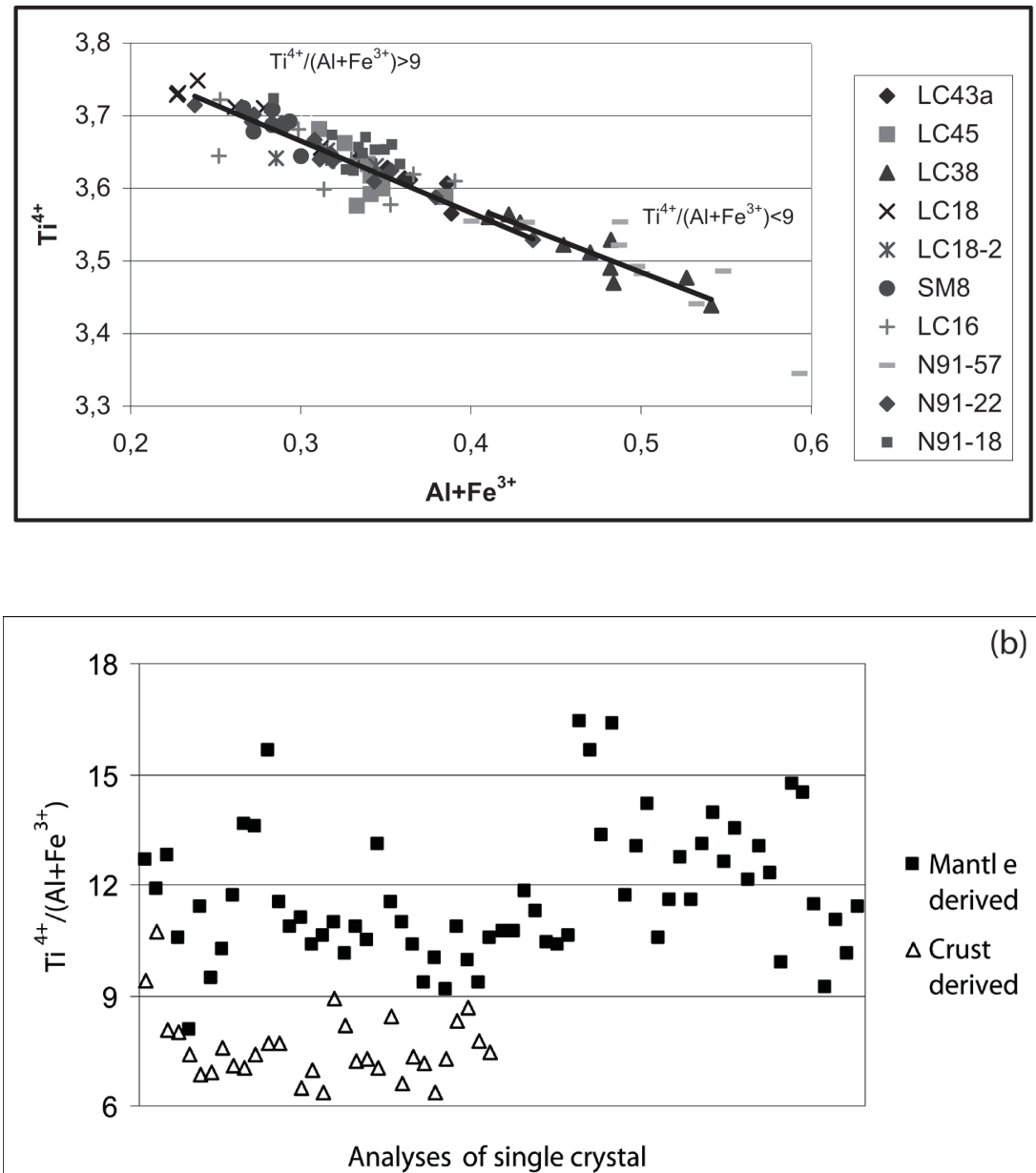

Figure $2 a, b$ - The relationship between $\mathrm{Ti}^{4+}$ apf and $\mathrm{Al}+\mathrm{Fe}^{+3}$ apf and the definition of two groups $A$ and $B$, respectively.

lack of accurate estimates of $\mathrm{H}, \mathrm{F}, \mathrm{REE}$ and other minor elements. Iron is reported as $\mathrm{Fe}_{2} \mathrm{O}_{3}$. In this work, the unit formula reported in Table 2 has been obtained based on five oxygen atoms. The $\mathrm{OH}$ apfu was calculated following Enami et al (1993).

\section{RESULTS}

\section{ISOTOPIC DATA}

Titanite crystals are near euhedral (N-57, LC43 and LC45) to subanedral (N-18, N-22, LC38, LC18, LC16, SM8), ranging in size from 50 to $200 \mu \mathrm{m}$, and no significant zoning was observed with the exception of grains from sample N-57. Crystal morphology, intragrain homogeneity and isotopic data are good evidences for titanite crystallization in equilibrium with the surrounding biotite and hornblende.

The wide titanite age spectrum is a consequence of distinct magmatic ages and metamorphic histories of studied plutons (Table 1). Granitoid plutons from the cratonic domain were not affected by the Neoproterozoic Brasiliano Orogeny, but record a Paleoproterozoic event dated at ca. 2120-2050 Ma (Noce et al. 1998). Titanite grains from the Archean granite (N-57) suffered partial lead-loss due to this event, while titanite ages for the Paleoproterozoic pluton $(\mathrm{N}-18 / \mathrm{N}-22)$ are close to the intrusion age.

The Araçuaí Orogen records a syncollisional tectono-metamorphic event dated at 585-560 Ma, and a late orogenic thermal episode related to the gravitational collapse of the orogen, dated at 535-500 Ma (Noce et al. 2004). Titanite ages of the granitoid plutons located within the orogenic domain are all Neoproterozoic, regardless their magmatic age. For most samples, the combination of resetting and/or partial lead-loss during two thermal episodes resulted in a complex titanite age pattern.

\section{MINERAL CHEMISTRY}

A remarkable difference in titanite composition is disclosed by two distinct groups of granitoid plutons, especially concerning $\mathrm{Ti}^{4+}, \mathrm{Al}^{3+}, \mathrm{Fe}^{3+}$ and $\mathrm{F}^{-}$contents. Titanite crystals from subduction-related plutons with an important mantelic contribution (and/or mafic lower crust) yield higher concentrations of $\mathrm{Ti}$ and lower concentrations of $\mathrm{Al}+\mathrm{Fe}^{3+}$, while opposite values are found in titanites from high fractioned crust-derived plutons (Table 2). The first group (Group A) comprises 
Table 2 - Average chemical composition (wt\%) and unit formula of titanite

\begin{tabular}{|c|c|c|c|c|c|c|c|c|c|c|}
\hline \multicolumn{8}{|c|}{ Mantle derived } & \multicolumn{3}{|c|}{ Crust derived } \\
\hline & $\mathrm{LC} 45$ & $\mathrm{LC} \mathrm{43a}$ & LC 18 & LC 18-2 & $\mathrm{N}-18$ & $\mathrm{~N}-22$ & SM- 8 & $\mathbf{N}-57$ & LC 16 & LC 38 \\
\hline $\mathrm{SiO}_{2}$ & 30,08 & 29,73 & 30,17 & 29,98 & 29,68 & 30,40 & 29,86 & 29,43 & 30,37 & 29,98 \\
\hline $\mathrm{TiO}_{2}$ & 36,94 & 36,65 & 38,09 & 37,10 & 37,19 & 37,77 & 37,46 & 35,52 & 37,54 & 35,71 \\
\hline $\mathrm{Al}_{2} \mathrm{O}_{3}$ & 1,70 & 1,60 & 1,38 & 1,64 & 1,30 & 1,89 & 1,37 & 1,70 & 1,93 & 2,38 \\
\hline $\mathrm{Fe}_{2} \mathrm{O}_{3}$ & 0,92 & 1,32 & 0,57 & 0,71 & 1,51 & 0,36 & 0,82 & 1,85 & 0,31 & 1,16 \\
\hline $\mathrm{MnO}$ & 0,11 & 0,11 & 0,07 & 0,07 & 0,00 & 0,00 & 0,11 & 0,00 & 0,06 & 0,12 \\
\hline $\mathrm{CaO}$ & 28,06 & 26,79 & 27,92 & 27,68 & 27,80 & 28,70 & 27,59 & 26,62 & 28,51 & 27,34 \\
\hline $\mathrm{Ce}_{2} \mathrm{O}_{3}$ & 0,00 & 0,24 & 0,01 & 0,03 & 0,33 & 0,01 & 0,31 & 0,56 & 0,01 & 0,16 \\
\hline $\mathrm{Y}_{2} \mathrm{O}_{3}$ & 0,09 & 1,75 & 0,20 & 0,88 & 0,00 & 0,00 & 0,28 & 0,00 & 0,05 & 0,43 \\
\hline $\mathrm{Nd}_{2} \mathrm{O}_{3}$ & nd & nd & nd & nd & 0,23 & 0,06 & nd & 0,37 & nd & nd \\
\hline $\mathrm{Nb}_{2} \mathrm{O}_{5}$ & nd & nd & nd & nd & 0,14 & 0,15 & nd & 0,29 & nd & nd \\
\hline $\mathrm{H}_{2} \mathrm{O}^{-}$ & 0,21 & 0,28 & 0,15 & 0,26 & 0,96 & 1,03 & 0,21 & 0,87 & 0,19 & 0,25 \\
\hline F & 0,39 & 0,29 & 0,32 & 0,22 & 0,39 & 0,29 & 0,25 & 0,53 & 0,38 & 0,62 \\
\hline $\mathrm{O} \equiv \mathrm{F}$ & 0,16 & 0,12 & 0,13 & 0,09 & 0,16 & 0,12 & 0,11 & 0,22 & 0,16 & 0,26 \\
\hline TOTAL & 98,33 & 98,64 & 98,75 & 98,48 & 99,36 & 100,54 & 98,13 & $\mathbf{9 7 , 5 2}$ & 99,20 & 97,90 \\
\hline $\mathrm{Si}^{4+}$ & 3,92 & 3,90 & 3,91 & 3,91 & 3,88 & 3,90 & 3,91 & 3,91 & 3,91 & 3,92 \\
\hline $\mathrm{Ti}^{4+}$ & 3,62 & 3,61 & 3,71 & 3,64 & 3,66 & 3,65 & 3,69 & 3,55 & 3,64 & 3,51 \\
\hline $\mathrm{Al}^{3+}$ & 0,26 & 0,25 & 0,21 & 0,25 & 0,20 & 0,29 & 0,21 & 0,27 & 0,29 & 0,37 \\
\hline $\mathrm{Fe}^{3+}$ & 0,08 & 0,12 & 0,05 & 0,06 & 0,13 & 0,03 & 0,07 & 0,17 & 0,03 & 0,10 \\
\hline $\mathrm{Mn}^{2+}$ & 0,02 & 0,02 & 0,01 & 0,01 & 0,00 & 0,00 & 0,02 & 0,00 & 0,01 & 0,02 \\
\hline $\mathrm{Ca}^{2+}$ & 3,92 & 3,76 & 3,88 & 3,87 & 3,89 & 3,95 & 3,87 & 3,79 & 3,94 & 3,83 \\
\hline $\mathrm{Ce}^{3+}$ & 0,00 & 0,01 & 0,00 & 0,00 & 0,02 & 0,00 & 0,01 & 0,03 & 0,00 & 0,01 \\
\hline $\mathrm{Y}^{3+}$ & 0,01 & 0,12 & 0,01 & 0,06 & 0,00 & 0,00 & 0,02 & 0,00 & 0,00 & 0,03 \\
\hline $\mathrm{Nd}^{3+}$ & 0,00 & 0,00 & 0,00 & 0,00 & 0,01 & 0,00 & 0,00 & 0,02 & 0,00 & 0,00 \\
\hline $\mathrm{Nb}^{5+}$ & 0,00 & 0,00 & 0,00 & 0,00 & 0,01 & 0,01 & 0,00 & 0,02 & 0,00 & 0,00 \\
\hline $\mathrm{F}^{-}$ & 0,16 & 0,12 & 0,13 & 0,09 & 0,16 & 0,12 & 0,10 & 0,22 & 0,16 & 0,26 \\
\hline $\mathrm{OH}^{-}$ & 0,18 & 0,24 & 0,13 & 0,22 & 0,84 & 0,88 & 0,18 & 0,21 & 0,16 & 0,21 \\
\hline
\end{tabular}
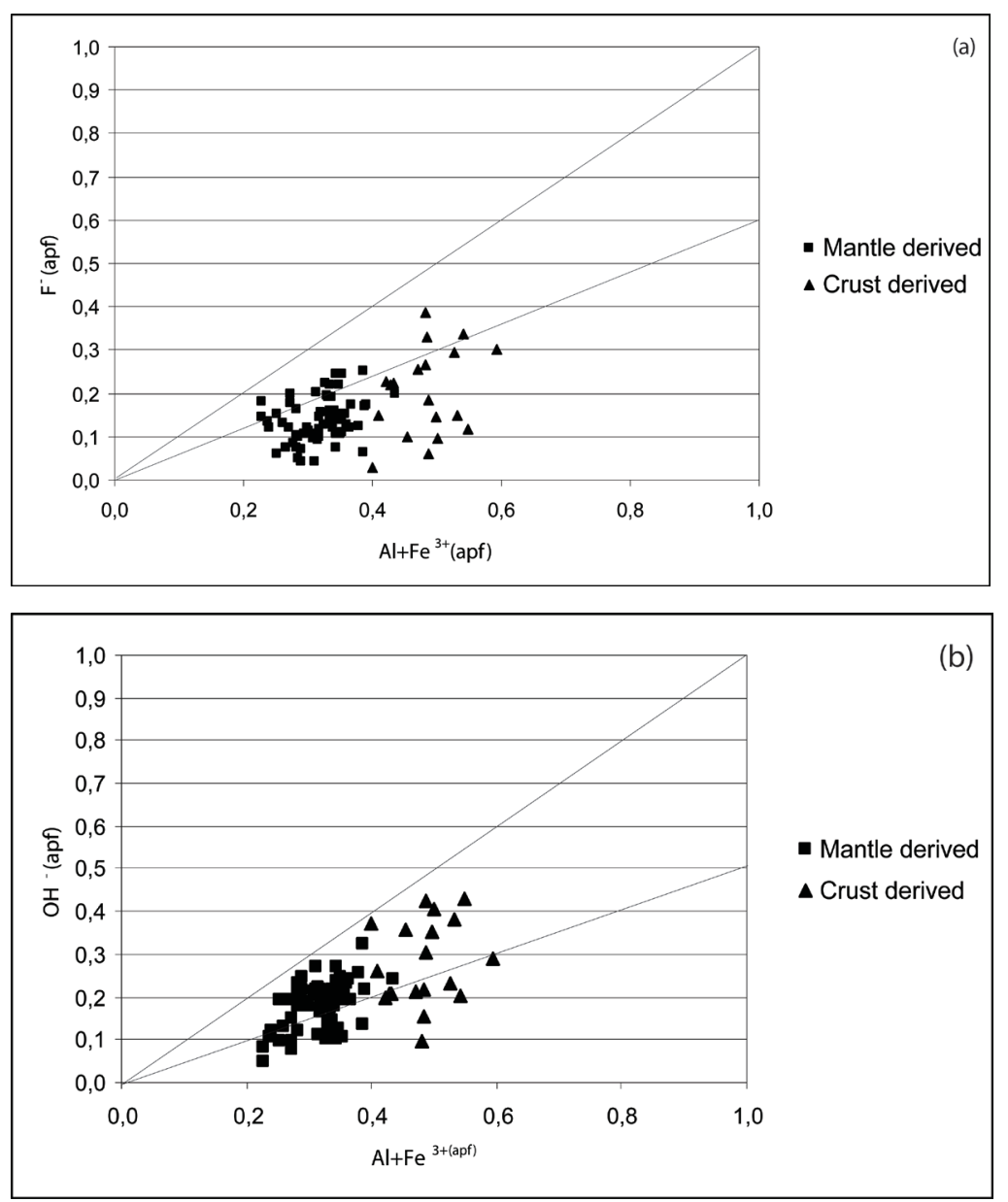

Figure 3 a, $b-\mathrm{OH}^{-}$versus $\mathrm{Al}+\mathrm{Fe}^{+3}$ and $\mathrm{F}$ - versus $\mathrm{Al}+\mathrm{Fe}^{+3}$ substitutions respectively 


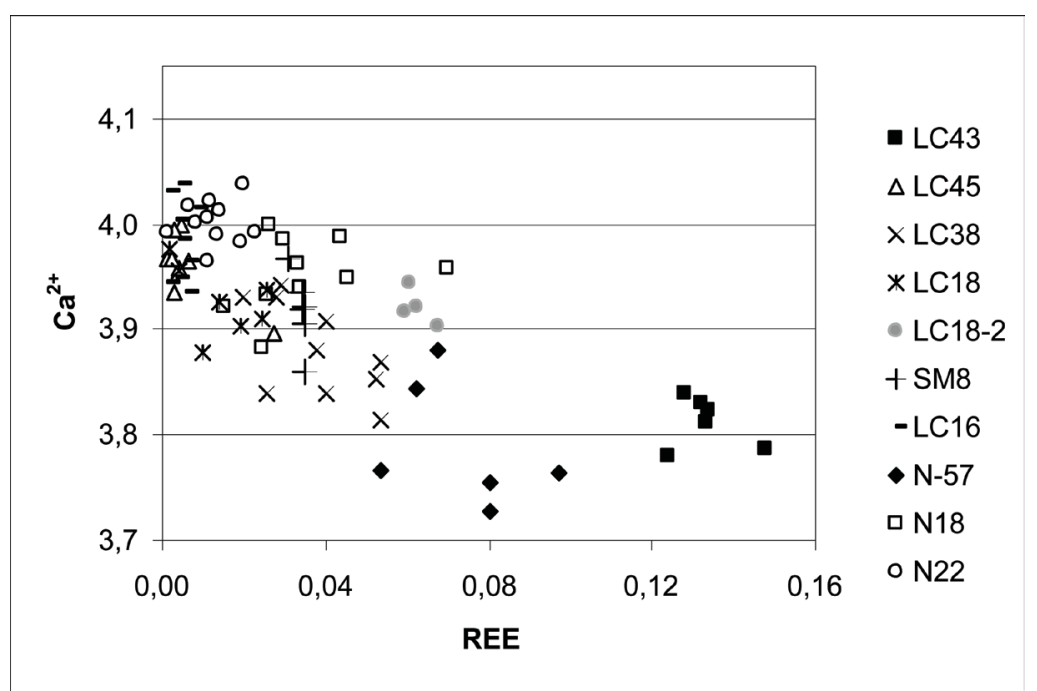

Figure 4: Ca ions versus REE contents to the studied samples

Archean TTG gneiss samples (LC45, LC43 and LC18), the Paleoproterozoic tonalite plutons $(\mathrm{N}-18 / \mathrm{N}-22$ and LC16), and the pre-collisional Brasilândia tonalite of Neoproterozoic age (SM8). The second group (Group B) includes a high-K Archean granite (N-57) and two Neoproterozoic granitoid bodies related to the sincollisional stage of the Araçuaí Orogen (LC38 and MU56). The two groups of granitoids can be distinguished according to the titanite $\mathrm{Ti}^{4+} /\left(\mathrm{Al}+\mathrm{Fe}^{3+}\right)$ ratio values. Group $\mathrm{A}$ has $\mathrm{Ti}^{4+} /\left(\mathrm{Al}+\mathrm{Fe}^{3+}\right)$ ratio values $>$ 9, whereas Group B has lower values $(<9$; Fig 2a,b).

It may be concluded that $\mathrm{Al}+\mathrm{Fe}^{3+}$ and $\mathrm{Ti}^{4+}$ substitutions involve the entrance of $\mathrm{F}^{-}$and $\mathrm{OH}^{-}$ ions (Fig 3a,b). Titanite crystals from Group A plutons plot roughly close to the $\mathrm{Al}-\mathrm{OH}$ end-member CaAlSiO4 $(\mathrm{OH})$, while titanite crystals from Group B have a more variable composition. There is a negative correlation between $\mathrm{Al}+\mathrm{Fe}^{3+}$ and $\mathrm{Ti}^{4+}$ contents, and a positive correlation between $\mathrm{F}^{-}$and $\mathrm{OH}^{-}$ions, implying the substitutions can be coupled: $\mathrm{CaTiO} \rightarrow \mathrm{Ca}\left(\mathrm{AlFe}^{3+}\right)$ FTi and $\mathrm{Ca}\left(\mathrm{AlFe}^{3+}\right) \mathrm{OHTi}$. In this context, a greater fluid content seems to be present in crust-derived plutons (Group B) because of the positive correlation between $\mathrm{F}$ and $\mathrm{OH}$ contents and $\mathrm{Al}+\mathrm{Fe}^{3+}$ contents.

In Group B Neoproterozoic plutons (samples LC-38 and Mu-56a), a fraction of the iron must have oxidized during the generation of large volumes of fluids, and as a consequence $\mathrm{CaTiO} \rightarrow \mathrm{Ca}\left(\mathrm{AlFe}^{3+}\right) \mathrm{F}$ substitution took place at the time of crystallization. The same hypothesis can be admitted concerning the Group B Archean pluton (sample N-57), but in this case the $\mathrm{CaTiO} \rightarrow \mathrm{Ca}\left(\mathrm{AlFe}^{3+}\right)$ $\mathrm{OH}$ substitution occurred preferentially. This significant fluid activity disclosed by crust-derived granitoids can be related to fractioned melting. According to Frank \& Spear (1985), Carswell et al. (1996) and Markl \& Piazolo (1999), the It is considered a petrogenetic indicator, according to studies developed on distinct tectonic domains .

According to the chemical data (Table 2) a negative correlation between $\mathrm{Al}+\mathrm{Fe}^{3+}$ and $\mathrm{Mn}$ contents may also be inferred, since there is no other correlation between $\mathrm{Mn}^{2+}$ and $\mathrm{Ca}^{2+}$ ions. Si ions seem to be sufficient to nearly full the tetrahedron site. Ca contents are similar and invariable in all samples, ranging from 3.7 to 4.0 apfu, and no substitution can be established. There is only a slight negative correlation between REE contents and $\mathrm{Ca}$ ions. These evidences suggest that the entrance of $\mathrm{Al}+\mathrm{Fe}^{3+}$ at octahedral site can favors the incorporation of smaller cations and available fluid, what can be well identified by the nature of the rocks.

\section{CONCLUSIONS}

Titanite crystals from granitoid plutons with magmatic ages ranging from Archean to Neoproterozoic, and intruded into distinct tectonic domains, underwent a complex history of partial lead-loss to resetting during successive thermal events. Nevertheless, their original bulk composition has been preserved. Analytical techniques applied in this study show that $\mathrm{Ti}$ and $\mathrm{Ca}$ sites of titanite crystal are independent since the $\mathrm{Ca}$-site is affected by tecnometamorphic events as evidenced by $\mathrm{U}-\mathrm{Pb}$ isotopic data while Ti-octaedral site substitutions are directly related with the bulk composition or nature of the rocks.

The majority of titanite crystal chemical analyses for samples LC-38 and N-57, which are the most fractionated granites, yield $\mathrm{Ti}^{4+} / \mathrm{Al}+\mathrm{Fe}^{3+}<9$. On the other hand, TTG and tonalite samples presents $\mathrm{Ti}^{4+} /$ $\mathrm{Al}+\mathrm{Fe}^{3+}>9$. Therefore, this ratio can be used as a petrogenetic pattern to distinguish mantle from crustal sources and/ or eventually mixing of sources.

\section{ACKNOWLEDGHMENTS}

The authors are indebted to the Brazilian research-founding agencies: Conselho Nacional de Pesquisa (CNPq) (Danielle Piuzana - Grant 300121/02-4) and CAPES/PRODOC (Cristiane Castañeda). 


\section{REFERENCES CITED}

Carswell, D.A.; Wilson, R.N.; Zhai, M. 1996. Ultra-high pressure aluminous titanites in carbonate bering eclogites at Ahuanghe in Dasbieshan, central China. Mineralogical Magazine, 60, 461-471

Deer, W.A.; Howie, R.A.; Zussman, J. 1992. An Introduction to the rock-forming minerals. 2 ed. Longman House, England, 696p.

Enami, M., Suzuki, K., Liou, J.G., Bird, D.K. 1993. Al-Fe ${ }^{3+}$ and F-OH substitutions in titanite and constraints on their P-T dependence. Eur. J. Mineral., 5,:219-231.

Frank, G. \& Spear, F.S. 1985. Aluminous titanite (sphene) from the eclogite zonte, south-central Tauern Window, Austria. Chemical Geology, 50: 33-46.

Frost, B.R., Chamberlain, K.R., Schumacher, J.C. 2000. Sphene (titanite): phase relations and role as a geochronometer. Chemical Geology, 172: 131-148.

Kazonovitz, E. B.\& Wolf, M.B. 2002. Fluorine partititoning between granitic melt and titanite. North Central Section $\left(36^{\text {th }}\right)$ and Southeastern Section (51 $\left.1^{\text {st }}\right)$, GSA Joint Annual Meeting. Paper $\mathrm{n}^{\circ} 33$.

Krogh, T.E. 1973. A low-contamination method for hydrothermal decomposition of zircon and extraction of $\mathrm{U}$ and $\mathrm{Pb}$ for isotopic age determinations. Geochimica et Cosmochimica Acta, vol. 37, Issue 3, pp.485-494.

Lambert, R.St.J, \& Holland, J.G. 1974. Yttrium geochemistry applied to petrogenesis utilizing calcium-yttrium relationships in minerals and rocks. Geochimica et Cosmochimica Acta, vol. 38, Issue 9, pp.1393-1414.

Ludwig K.R. 1993. PBDAT. A computer program for processing $\mathrm{Pb}$ U-Th isotope data. USGS Open File Report 88-542, 34p.

Ludwig, K.R., 2001. User's Manual for Isoplot/Ex v. 2.47. A Geochronological Toolkit for Microsoft Excel. BGC Special Publication 1a, Berkeley, 55 pp.

Machado, N., Noce, C.M., Ladeira, E.A. and Belo de Oliveira, O., 1992. U-Pb geochronology of Archean magmatism and Proterozoic metamorphism in the Quadrilátero Ferrífero, southern São Francisco craton, Brazil. Geological Society of America Bulletin, 104: 1221-1227.

Machado, N. \& Carneiro, M.A., 1992. A major Archean tectonothermal event in the São Francisco shield, Brazil: U-Pb evidence from the Quadrilátero Ferrífero, Minas Gerais. Canadian Journal of Earth Sciences, 29: 2341-2346.
Mark1,G. \& Piazolo, S. 1999. Stability of high-Al titanite from low pressure calcssilicates in light of fluid and host-rock composition. American Mineralogist, 84: 37-47.

Noce, C.M. 1995 Geocronologia dos eventos magmáticos, sedimentares e metamórficos na região do Quadrilátero Ferrífero, Minas Gerais. São Paulo, 128 p. (Tese de Doutoramento, Universidade de São Paulo).

Noce, C.M.; Machado, N. ; Teixeira, W. 1998 . U-Pb geochronology of gneisses and granitoids in the Quadrilátero Ferrífero (Southern São Francisco Craton): age constraints for Archean and Paleoproterozoic magmatism and metamorphism. Rev Bras Geo28(1): 95-102.

Noce C.M., Teixeira W, Quéméneur J., Martins V.T.S. and Bolzachini E., 2000. Isotopic signature of Proterozoic granitoids from the Southern São Francisco Craton and implications for the evolution of the Transamazonian Orogeny. Journal of South American Earth Sciences, 13: 225-239.

Pedrosa Soares, A.C.; Noce, C.M.; Wiedemann, C.M.; Pinto, C.P. 2001. The Araçuaí-West-Congo Orogen in Brazil: an overview of a confined orogen formed during Gondwanaland assembly. Precamb. Res., 110, p. 307-323.

Quéméneur J.J.G. \& Noce, C.M. 2000 Geochemistry and petrology of felsic and mafic suites related to the Paleoproterozoic Transamazonian Orogeny in Minas Gerais, Brazil. Rev Bras Geo 30: 87-90.

Silva, J.M.R.; Lima, M.I.C. de; Veronese, V.F.; Ribeiro Jr, R.N.; Rocha, R.M.; Siga Jr, O. (1987) Geologia da Folha Rio Doce. In: Projeto RadamBrasil, Folha SE-24 Rio Doce. IBGE-RJ. 548 p.

Silva, L.C. da, Armstrong, R., Noce, C.M., Pimentel, M., PedrosaSoares, A.C., Leite, C., Vieira, V.S. and Paes, V.C., 2002b. Reavaliação U-Pb SHRIMP em terrenos pré-cambrianos Brasileiros. Parte II: Orógeno Araçuaí, Cinturão Mineiro e Cráton São Francisco meridional. Revista Brasileira de Geociências, 32: $513-528$

Tiepolo M., Oberti R., and Vannucci R. 2002. Trace-element incorporation in titanite: Constraints from experimentally determined solid/liquid partition coefficients. Chemical Geology 191, 105-119.

Tropper, P., Manning, C.E., Essene, E.J. 2002. The Substitution of Al and $\mathrm{F}$ in Titanite at High Pressure and Temperature: Experimental Constraints on Phase Relations and Solid Solution Properties. Journal of Petrology, Vol. 43, N.10: 1787-1814. 